\title{
JANÁČKOVA ORGANIZAČNÍ ČINNOST V DRUŽSTVU NÁRODNÍHO DIVADLA V BRNĚ
}

Téma tohoto příspěvku je pojato, pochopitelně v širších souvislostech, $\mathrm{v}$ knížce Divadlo nesmí býti lidu komedii, ${ }^{1}$ a proto bych se zastavil pouze u nejdůležitějších Janáčkových aktivit v Družstvu českého Národního divadla v Brně.

Asi každý historik narazil ve své badatelské činnosti na místa, na kterých již po generace leží stín pochybností, či jsou zcela nedořešena. I janáčkologové mají několik takových míst. Alespoň pro mě jsou takové otazníky spojené s Janáčkovým vztahem $\mathrm{k}$ institucím. První nedořešenou otázkou pro mě zůstává skladatelovo účinkování kolem roku 1866 v Meyerbeerově opeře Prorok na brněnské divadelní scéně. Mnoho energie jsem věnoval této otázce, abych v závěru musel konstatovat, že jsem na nic kloudného nepřišel. Podobně je to i s druhou otázkou, tedy jak dlouho a jak přesně vypadala Janáčkova činnost na kůru starobrněnského kláštera. Když jsem připravoval kapitolu o finanční situaci skladatele pro monografii Johna Tyrrella, ${ }^{2}$ seděl jsem týdny v Moravském zemském archivu a prohlédl tisíce účtů a dokumentů, které by mohly alespoň napovědět, kdy skladatel z kůru odešel. A opět nic.

Jsem velmi rád, že alespoň ve třetím případě jsem byl úspěšnější. Ten třetí prípad je spojen se skladatelovým působením v Družstvu českého Národního divadla v Brně, kde jsme byli z literatury informováni, že byl prostě náhradníkem družstva. Tedy informace velmi vágní. Naštěstí Janáčkovu činnost $\mathrm{v}$ této organizaci, díky zachovaným pramenům, lze velmi detailně popsat. ${ }^{3}$

Jelikož jde o velmi rozsáhlý okruh problémů, omezím se pouze na základní informace. Když se 24. ledna 1881 poprvé sešel výbor Družstva českého Národního divadla, Janáček v něm nefiguroval. Proč? Odpověd' je nasnadě. Mla-

1 ZAHRÁDKA, Jiří. Divadlo nesmí býti lidu komedií. Leoš Janáček a Národní divadlo v Brně. Brno: Moravské zemské muzeum, 2012. London: Faber and Faber, 2006.

3 Prameny včetně zápisů ze schůzí jsou uloženy v Archivu města Brna, fond Družstva českého Národního divadla v Brně - R 35. 
dý skladatel v té době ještě nebyl ve společnosti plně etablován, ačkoliv jeho postavení mezi brněnskými Čechy sílilo. Není tedy překvapením, že nedlouho po otevření Prozatímního českého národního divadla na Veveří ulici v prosinci 1884 byl Janáček Družstvem přizván k aktivní spolupráci. Od kdy byl mladý skladatel přispívajícím členem Družstva, nevíme, ale lze předpokládat, že se jím stal krátce po založení.

Do výboru Družstva byl Janáček poprvé pozván na schůzi 8. února 1886 na návrh Kuneše Kunce, ale schůze se nezúčastnil. Teprve 10. června téhož roku byl skladatel př́itomen spolu s dalšími osobnostmi na schůzi enkety, což byla jakási širší debata o některých problémech Prozatímního národního divadla. Především se zde projednával název divadla - zda ponechat v názvu označení „národní“, které bylo úzce spojeno s pražskou scénou. Janáček byl toho názoru, že má být slovo „národní“ v názvu divadla zachováno, ale doplněno ještě o označení „prozatímní". Další část debaty byla věnována problematice převzetí divadla do vlastní režie Družstva.

Členem výboru Družstva se Janáček stal až 16 . ledna 1887, kdy byl na valné hromadě jednohlasně zvolen, avšak pouze náhradníkem kurie členů přispívajících a činných. Jako náhradník se pochopitelně schůzí neúčastnil. Na valné hromadě Družstva 29. ledna 1888 již Janáček do výboru navržen nebyl. Opětovně byl výboru doporučen na valné hromadě 3 . března 1889 , kdy byl navržen do kurie členů přispívajících a činných, ale do výboru byli zvoleni Kuneš Kunz a V.[?] Veselý (po 18 hlasech), přičemž Janáček získal pouhý 1 hlas. V následující volbě pak byl 18 hlasy zvolen opět náhradníkem. Za aktivního člena výboru Družstva byl tak zvolen až na valné hromadě 12. dubna 1891. Janáček vstoupil do výboru Družstva v době, kdy Družstvo přejalo provoz divadla do vlastní režie (tento vytoužený stav od samého počátku narážel na nesnáze především finančního rázu, přesto byl zachován až do roku 1898).

Od první schůze nového výboru Družstva, která se konala 14. dubna 1891, Janáček navštěvoval až na výjimky všechny výborové schůze, které se konaly jednou týdně. Z jeho prvního období, kdy ve výboru Družstva působil, připomeňme alespoň prosazování Dvořákových oper do repertoáru divadla, dưraz na zřízení vlastního divadelního notového archivu, zvětšení orchestřiště v divadle na Veveří ulici, navýšení hráčů v orchestru či nakupování nástrojů. Poslední schůze tohoto období, které se Janáček zúčastnil, byla 8 . května 1896 . Zde se řešila možnost nahradit divadelního ředitele Jana Pištěka Pavlem Švandou ze Semčic ml. Janáček se proti tomuto návrhu vyslovil s obavou, že není vhodné v dané chvíli experimentovat. V hlasování byl však přijat návrh na změnu ředitele. To mohlo zapříčinit, že na další schůzi 26. května 1896 poslal Janáček písemně svou rezignaci. Na jeho místo ve výboru nastoupil malír a fotograf Josef Ladislav Šichan, Janáčkův rodinný př́tel a svatební svědek. Ač se během pětiletého působení Janáčka ve výboru Družstva podařilo prosadit mnoho pozitivního, napřs. vlastní režie divadla, skladatelova snaha o zkvalitnění a rozšíření operního orchestru zůstala nenaplněna.

Další Janáčkova činnost je datována 13. březnem 1909. Janáček nastoupil do výboru v době, kdy procházelo Družstvo obrovskou krizí. Př́ičinou celé- 
ho skandálu s politickým kontextem byla volba místa, kde měla být vystavěna nová budova českého Národního divadla. Koncem roku 1907 podalo Družstvo na zemský výbor žádost o přenechání pozemku v zemských lužáneckých sadech. Žádost byla na nátlak německých poslanců v polovině roku 1908 odložena ad acta, přestože měli Češi v zemském výboru převahu a byl zde mimo jiné zastoupen i předseda Družstva českého Národního divadla JUDr. Otakar baron Pražák. To bylo pro brněnskou českou minoritu deprimující.

Starý výbor Družstva vedený Dr. Otakarem baronem Pražákem a Ing. Michalem Ursínim, který byl nařčen z podezřelých machinací spojených s rychlou výstavbou divadla na místě stávajícího divadla na Veveří ulici, a tím de facto vycházejících zájmům brněnských Němců, byl nucen rezignovat a po bouřlivé valné hromadě 13. března 1909 se do výboru Družstva dostali revolucionár̆i s novými vizemi jako byl Arnošt Heinrich a také Leoš Janáček. Ti měli vizi vystavět nové divadlo v lužáneckých sadech a zavést fungování divadla ve vlastní režii Družstva. Janáček dokonce vypracoval obsáhlý systém výchovy mladých zpěváků za pomoci brněnských hudebních škol, ale veškeré snahy postupně nahrazovaly staré zájmy.

Co se týče sporu o místo pro výstavbu nového českého divadla, to mělo být s konečnou platností vystavěno na místě stávající budovy na rohu Radvitova náměstí a Veveří ulice. Ale i na tomto místě byla výstavba odložena a s tím zanikla i komise pro př́pravu vlastní režie, nebot' tento organizační model měl začít fungovat až v novém divadle. Není tedy divu, že rozčarovaný Janáček později chodil na schůze jen sporadicky a jeho činnost ve výboru byla prakticky formální. Žádná z jeho vizí, ani nová divadelní budova v lužáneckých sadech ani divadlo ve vlastní režii, se nenaplnila. Nakonec zaslal 16. června 1913 výboru Družstva svou rezignaci. ${ }^{4}$

Znovu se Leoš Janáček objevil ve výboru Družstva až v překotných dnech roku 1918. Krátce po převratu se uskutečnila 9. prosince 1918 řádná valná hromada Družstva, kdy byl do výboru potřetí a naposledy zvolen i Leoš Janáček. Ten také zahájil 12. prosince 1918 jako nejstarši člen výboru první schůzi, kde emotivně pohovořil o zářivé budoucnosti brněnského Národního divadla. Poté byl jednomyslně zvolen předsedou družstva Alois Mrštík. Ten se však výborových schůzí prakticky neúčastnil a předsednictví de facto převzal sám Janáček, přičemž podepisoval i zápisy schůzí. Janáček, který měl na rozdíl od minulých období ve výboru zásadní vliv, prosadil mnoho ze svých vizí a nápadů, z nichž připomeňme alespoň tyto:

Prosadil, aby brněnské Národní divadlo provedlo v německém Městském divadle 21. prosince 1918 Smetanovu Libuši, aby tak město u prŕležitosti př́ijezdu prezidenta T. G. Masaryka do vlasti jasně deklarovalo své další politické směřování.

Patrně nejdůležitějším krokem bylo Janáčkovo velmi striktní prosazení nového vedení Národního divadla, především Františka Neumanna do funkce šéfa 
opery. Janáček svou neústupností i politickou zručností prosadil Neumanna, ač ve hře byly takové osobnosti jako Ostrčil nebo Čelanský. Volba to byla nesporně št’astná.

Poslední moment, který bych vyzdvihl, je Janáčkovo členství v komisi jednající o předání německého Městského divadla do rukou českého Národního divadla.

Problém dohody s brněnskými Němci o užívání budovy Městského divadla byl značně složitý, politicky choulostivý a veřejností sledovaný. Na jedné straně zněl názor, že Němci mají předat divadlo bez kompromisů českému Národnímu divadlu (jak tvrdil nap̌r. Arnošt Heinrich); druhá strana uvažovala o kompromisu a dohodě (např. padl návrh, aby Češi užívali divadlo od 1. září do 15 . března a poté by se česká představení hrála v Bratislavě, zatímco Němci by hráli v budově na konci sezóny, či vstřícnější návrh, který počítal s tím, že by Němci hráli vždy v pondělí a úterý každého týdne sezóny).

Napjatá situace se natolik vyostřila, že bylo výborem 8. dubna 1919 rozhodnuto, aby byla vyslána deputace k prezidentu Masarykovi, přičemž užší složení mělo být následující: Leoš Janáček, Dr. Jaroslav Helfert, JUDr. František Koželuha, Jiř́i Mahen a Václav Štech. Jednání se však stále komplikovalo a stávalo se především v otázce kompetencí natolik nepřehledné, že se Janáček na schůzi 15. dubna 1919 vzdal funkce „náměstka“ pro vyjednávání. Deputace se uskutečnila 26. dubna 1919, dle Janáčkova zápisníku na Pražském hradě o 11 hodině. O jejím průběhu jsme informováni ze zápisu výborové schůze ze 30. dubna 1919: „Dr. Koželuha referuje o tom, jak deputace Družstva pořídila u prezidenta Masaryka. Masaryk, vyslechnuv naše požadavky, prohlásil, že otázka brněnského divadla je po výtce též otázka politická a že s té př́činy bylo by záhodno uzavřiti $s$ Němci kompromis. " Jednalo se i o možnosti pravidelného účinkování divadla v Bratislavě, avšak za podmínky, že útraty by musela hradit vláda. Masaryk v této věci prohlásil, že o tom bude dál jednat.

Ke kompromisu vybízel i sekční šéf Ministerstva školství a národní osvěty Jaroslav Kvapil. Tak se stalo, že kompromis byl nakonec tento: Němci měli hrát v Městském divadle od nové sezóny v pondělí a úterý, Češi po zbytek týdne, v Redutě pak naopak Němci od středy do neděle, Češi první dva dny v týdnu. Národní divadlo tak v Městském divadle uvádělo operu, v Redutě činohru a ve starém divadle na ulici Veveří operetu, přes počáteční tlaky zbudovat zde biograf.

Janáček se kromě tohoto odpovědného úkolu aktivně podílel na běžné činnosti výboru, především konzultoval kroky nového šéfa týkající se sestavování operního orchestru.

Svou v pořadí třetí a poslední rezignaci na členství ve výboru Družstva Janáček podal na schůzi 21. června 1920.

Janáčkova spolupráce s Družstvem brněnského Národního divadla byla jak vidno pestrá a oboustranně př́nosná. Jeho patrně nejvýznamnějším počinem v Družstvu bylo prosazení Františka Neumanna na pozici šéfa opery v roce 1919. Právě tato významná dirigentská osobnost $\mathrm{v}$ součinnosti s pragmatickým a or- 


\title{
ganizačně schopným ředitelem Václavem Štechem ukázala této instituci cestu k dramaturgicky progresivní, prosperující, moderní stř̌edoevropské scéně.
}

Jiří Zahrádka je kurátorem janáčkovských sbírek v hudebním oddělení Moravského zemského muzea v Brně. Pedagogicky působí na Ústavu hudební vědy FF MU v Brně.

\begin{abstract}
:
Leoš Janáček has joint the Družstvo committee of the Czech National Theater in Brno altogether three times. For the first time, not long after the Czech National Theater in Brno was opened, he was elected an alternate member of the curie of active and contributing members on 16th January 1887. He was not elected an active member of the committee until the general meeting held on 12th April 1891. When participating in the committee he boosted for instance orchestra pit widening, increasing the number of orchestra members, establishing a music archive or a musical instruments purchase. He voluntarily quitted the committee on 26th May 1896 and did not return until 13th March 1909 when the committee was raving with a major crisis caused by a dispute about the location of a new building of the Czech National Theater. The committee chiefs were even accused of manipulative negotiations, trading with Germans and non-transparent financial transactions. Among those who criticized this intrigue was Leoš Janáček. In the newly established committee he mainly urged for directing the theater by the committee itself and also for building a theater in the Lužánky park. Since he did not succeed in either, he resigned again on 16th June 1913. For the third and last time he joint the committee in the rapid days of 1918. Janáček was elected at the general meeting on 8th December 1918. Although Alois Mrštík was nominated as the head, the actual leader was Janáček himself. Among his major achievements we could name appointing František Neumann the opera director and participation of a negotiation committee in transferring the German City Theater under the Czech National Theater. Janáček handed in his third and last resignation at the committee meeting on 21st June 1920.

Janáček's co-operation with the Družstvo committee of the National Theater in Brno was diverse and mutually beneficial. Presumably, his most significant success was appointing František Neumann the opera director in 1919. This important conductor together with organization skills and pragmatic reasoning of the director Václav Štech led the institution to a dramaturgically progressive, thriving and modern Central European stage. Details can be found in the following document: Zahrádka, Jiř́: Theater must not be comedy for the people. Leoš Janáček and the National Theater in Brno. Moravian Museum, Brno 2012.
\end{abstract}

\section{Key words:}

Družstvo committee of the Czech National Theater in Brno, National Theater in Brno, opera, Leoš Janáček

\section{Bibliography:}

DÝMA, Josef. Ztráta 400.00 korun národniho jmění. Divadelní aféra. Vydal Josef Dýma v Brně [1908].

EICHLER, Karel. P. Pavel Křžžkovský. Brno: Tiskem a nákladem Papežské knihtiskárny benediktinů rajhradských, 1904.

FIRKUŠNÝ, Leoš. Dopisy Leoše Janáčka z archivu Družstva Národního divadla v Brně. In Musikologie I, Praha - Brno, Melantrich - Pazdírek, 1938, s.130-139. 
HELFERT, Jaroslav. Národní divadlo v Brně. Praha: Nakladatelství Bedřich Kočí, [1919].

HÝSEK, Miloslav. Dějiny českého divadla v Brně. Otisk z Hlídky 1907. Brno: Tiskem benediktinské knihtiskárny, 1907.

KRTIČKA, Stanislav. Brněnská hudebni epocha 1919-1941. Praha: Český hudební fond, 1954.

PROCHÁZKOVÁ, Jarmila. Prezident a skladatel. Opus musicum, 1990, roč. 24, č. 6, s. 168-182.

REKTORYS, Artuš (ed.). Korespondence Leoše Janáčka s Otakarem Ostrčilem. Janáčkův archiv, sv. 2. Praha: Hudební matice Umělecké besedy, 1948.

REKTORYS, Artuš (ed.). Korespondence Leoše Janáčka s Artušem Rektorysem. Janáčkův archiv, sv. 4. Praha: Hudební matice Umělecké besedy, 1949.

REKTORYS, Artuš (ed.). Korespondence Leoše Janáčka s Karlem Kovařovicem a ředitelstvím Národního divadla. Janáčkův archiv, sv. 7. Praha: Hudební matice, 1950.

ŠTECH, Václav. Džungle literární a divadelní. Praha: Nakladatelské družstvo Máje, [1938].

TAUŠ, Karel. 50 let českého Národního divadla v Brně. Brno: Nákladem Zemského divadla v Brně, 1934.

TYRRELL, John. Janáček, Years of a Life. Volume I. London: Faber and Faber, 2006.

WEYR, František. Paměti 2. (Za republiky 1918-1938). Brno: Atlantis, 2001.

ZAHRÁDKA, Jiří. Divadlo nesmí býti lidu komedií. Leoš Janáček a Národní divadlo v Brně. Brno: Moravské zemské muzeum, 2012.

Předložená práce vznikla za finanční podpory Ministerstva kultury v rámci institucionálního financování na dlouhodobý koncepční rozvoj výzkumné organizace Moravské zemské muzeum (DKRVO, MK000094862). 